\title{
PEMBUATAN MINUMAN FUNGSIONAL DARI MADU DAN EKSTRAK ROSELLA (Hibiscus sabdariffa Linn.)
}

\author{
Oleh: \\ Ningrum Dwi Hastuti *) \\ *) Tenaga Pengajar Politeknik Ketapang Kalimantan Barat
}

\begin{abstract}
Abstrak
Pengolahan rosella menjadi produk olahan memang perlu dikembangkan mengingat nilai jual yang lebih tinggi daripada bentuk segar atau kering (simplisia). Salah satu bentuk pengolahan rosella ini di dasarkan pada prilaku konsumen Indonesia yang memasak rosella dengan air mendidih pada suhu sekitar $100{ }^{\circ} \mathrm{C}$. Tujuannya adalah untuk memberikan warna pada minuman, mengurangi rasa asam dari rosella dimana seringkali kurang disenangi oleh konsumen (komunikasi dengan petani rosella, 2009). Namun belum diketahui efek pemanasan dengan cara direbus terhadap aktifitas antioksidan dari kelopak rosella yang diekstrak tanpa pelarut bahan kimia baik secara kuantitatif maupun kualitatif. Salah satu upaya untuk mempertahankan produk minuman rosella akibat pemanasan agar tetap berpotensi mempertahankan produk minuman rosella akibat pemanasan agar tetap berpotensi sebagai antioksidan alami, maka dikombinasikan dengan antioksidan alami lainnya seprti madu.

Penelitian dilaksanakan dalam dua tahap. Tahap 1 dilakukan untuk mengetahui pengaruh kombinasi perlakuan dari kombinasi perlakuan dari kondisi bahan baku dan suhu pemanasan pada rosella terhadap aktifitas antioksidan yang akan diaplikasikan pada minuman fungsioanal . penelitian ini menggunakan Rancangan Acak Kelompok (RAK) dua factor dengan variable terikat adalah rosella kering $\left(\mathrm{k}_{1}\right)$ dan rosella segar $\left(\mathrm{K}_{2}\right)$, sedangkan variable bebas adalah waktu (T) yang terdiri dari lima level, yaitu 0,5,10,15 dan 20 menit dan tiap perlakuan di ulang tiga kali. Tahap II menggunakan Rancangan Acak Kelompok (RAK) dua faktor dengan variable terikat adalah dengan kombinasi perlakuaan terbaik penelitian tahap I, sedangkan variable bebas adalah konsentrasi madu yang terdiri dari tiga level, yaitu $15 \% \mathrm{v} / \mathrm{v}, 30 \% \mathrm{v} / \mathrm{v}$ dan $45 \% \mathrm{v} / \mathrm{v}$. Perbedaan antar perlakuan dianalisis
\end{abstract}


dengan analisis sidik ragam, bila terdapat perbedaan nyata dilakukan uji DMRT taraf 5\%.

Kombinasi perlakuan terbaik pada tahap I untuk parameter aktifitas antioksidan dari perlakuan kondisi bahan baku terhadap waktu pemanasan diperoleh dari kombinasi perllakuan kelopak rosella kering yang dipanaskan selama 10 menit. Parameter aktifitas antioksidan pada perlakuaan terbaik tahap I adalah: kemampuan kelopak rosella untuk menangkap radikal bebas DPPH sebesar 75,59\%, total fenol sebesar 6,491 $\mathrm{mg} / \mathrm{g}$ dan total antosianin sebesar $3,862 \mathrm{mg} / \mathrm{g}$. senyawa yang berperan sebagai antioksidan pada kelopak rosella kering yang dipanaskan pada menit ke-10 adalah hydroxyl methyl furfurole pada puncak nomor 10 $(41,14 \%)$. Sedangkan spectrum inframerah dari kelopak rosella kering yang dipanaska selama 10 menit, dimana memberikan serapan yang paling dominan pada bilangan gelombang $3401,23 \mathrm{~cm}^{-1}$ (kuat lebar) yang kha untuk regangan gugus $\mathrm{OH}$, bilangan gelombang 1632,63 $\mathrm{cm}^{-1}$ khas untuk gugus keton (R-CO-R) dan bilangan gelombang $1741,6 \mathrm{~cm}^{-1}$ (kuat tajam) khas untuk regangan asam karboksilat $(\mathrm{RCOOH})$.

Kombinasi perlakuan terbaik pada tahap II untuk parameter organoleptik dari kombinasi ekstrak kelopak rosella kering yang dipanaskan selama 10 menit terhadap berbagai perlakuan konsentrasi madu diperoleh dari kombinasi konsentrasi madu $15 \%$ yaitu rerata kesukaan panelis terhadap rasa 7,65 (sangat suka), warna 3,96 (suka) dan aroma 7,4 (sangat suka). Sedangkan parameter aktifitas antioksidannya adalah: kemampun minuman fungsional rosella madu untuk menangkap radikal bebas DPPH sebesar 30,23\%, total fenol $0,59 \mathrm{mg} / \mathrm{g}$ dan total antisioninsebesar $1,24 \mathrm{mg} / \mathrm{g}$. senyawa yang berperan sebagai antioksidan pada minuman fungsional rosella madu adalah hydroxyl methyl furfurole pada puncak no $1(23,61 \%)$ gugus fungsi yang muncul pada minuman fungsional rosella madu seperti alcohol dan aldehida termasuk kedalam kelompok oxygenated.

Kata kunci: ekstrak rosella,antioksidan, perlakuan pemanasan, konsentrasi madu 
Tanaman rosella merupakan sejenis tanaman anggota Malvaceae dan populer di kalangan masyarakat, dan banyak digunakan sebagai minuman segar disebabkan aroma yang khas, mengandung asam sitrat dan malat sehingga mempunyai rasa mild asam manis yang segar dan khas dengan warna natural alami yang menarik. Antosianin merupakan pigmen alami yang memberi warna merah pada seduhan kelopak bunga rosella dan mempunyai sifat antioksidan yang kuat (Maryani dan Kristiana, 2007).

Beberapa penilitian telah dilakukan untuk mengetahui antioksidan pada rosella. Tsai, McIntosh, Pearce, Camden and Jordon (2002) telah meneliti kapasitas antioksidan dari bunga rosella dengan mengekstrak dalam larutan alkohol dan mereaksikannya dengan senyawa radikal bebas. Penelitian lain oleh Farombi and Fakoya (2005) mengenai rosella kering dari Nigeria yang diekstrak oleh pelarut etanol untuk mendapatkan fraksi kloroform terlarut (Chloroformsoluble Fraction-HSCF) dan frakasi etil asetat terlarut (Ethyl acetate-soluble Fraction-HSEA). Duh and Yen (1997) juga meneliti aktivitas antioksidan rosella yang dikeringkan dengan sinar matahari dan diekstrak dengan air menggunakan analisis DPPH.

Pengolahan rosella menjadi produk olahan memang perlu dikembangkan mengingat nilai jual yang lebih tinggi daripada bentuk segar atau kering (simplisia). Salah satu bentuk pengolahan rosella dapat dilakukan dengan perlakuan pemanasan, yaitu direbus. Pengembangan bentuk pengolahan rosella ini didasarkan pada perilaku konsumen Indonesia yang memasak rosella dengan air mendidih pada suhu sekitar $100^{\circ} \mathrm{C}$. Tujuannya adalah untuk memberikan warna pada minuman, mengurangi rasa asam dari rosella dimana seringkali kurang disenangi oleh konsumen (komunikasi dengan petani rosella, 2009).

Rosella merupakan tanaman yang sangat berpotensi dikembangkan menjadi minuman kesegaran dan kesehatan yang saat ini banyak diminati masyarakat. Salah satu upaya untuk mempertahankan produk minuman rosella akibat pemanasan agar tetap berpotensi sebagai antioksidan alami, maka dikombinasikan dengan 
antioksidan alami lainnya seperti madu. Jaya (2008) meneliti mengenai sifat antioksidan madu terhadap pemanasan rimpang jahe selama 6 menit dan penambahan $15 \mathrm{ml}$ madu untuk membuat minuman fungsional. Hasil penelitian menunjukkan bahwa perpaduan antara rimpang jahe dan madu dapat sinergis dan meningkatakan aktifitas antioksidan. Begitu pula dengan Brown, Henderson and Hunt (2006) yang melaporkan mengenai perpaduan antara jahe Thailand dengan madu/ propolis memiliki kemampuan sebagai penangkap radikal bebas yang tinggi.

Pengaruh pemanasan dari rosella tanpa bahan pelarut kimia dan pemanfaatan madu sebagai antioksidan untuk membuat formulasi minuman fungsional perlu dikaji lebih lanjut. Oleh karena itu, perlu dianalisis kadar total antosianin, total fenolik (sebagai asam galat) dan aktifitas antioksidan dengan menggunakan metode penangkap radikal bebas DPPH.

\section{Perumusan masalah}

1. Apakah tanaman rosella mengandung antioksidan?
2. Bagaimana kondisi bahan baku dan waktu pemanasan yang tidak menurunkan kadar antioksidan?

3. Berapakah kombinasi perlakuan antara ekstrak rosella dan madu untuk pembuatan minuman fungsional?

\section{Tujuan Penelitian}

Tujuan dari penelitian ini adalah :

1. Untuk mengetahui kandungan antioksidan dalam rosella.

2. Mendapatkan informasi kondisi bahan baku dan waktu pemanasan rosella yang tidak menurunkan kadar antioksidan.

3. Untuk mengetahui secara kuantitatif kombinasi perlakuan antara ekstrak rosella dan madu untuk membuat minuman fungsional.

\section{Manfaat Penelitian}

1. Memberikan data ilmiah mengenai perlakuan pemanasan terhadap antioksidan dari rosella.

2. Memberikan informasi kepada kalangan industri minuman fungsional/ obat tradisional mengenai minuman yang dapat dibuat dari bahan alami tanpa bahan kimia. 


\section{Hipotesis}

1. Diduga tanaman rosella mengandung antioksidan.

2. Diduga terdapat perbedaan antara rosella segar dan kering pada perlakuan pemanasan terhadap aktivitas antioksidan.

3. Diduga kembinasi perlakuan ekstraksi bunga rosella dan konsentrasi madu terhadap kualitas minuman fungsional.

\section{METODE PENELITIAN}

Tempat dan Waktu Penelitian

Penelitian ini dilakukan di laboratorium Teknologi Hasil Pertanian, Fakultas Teknologi Pertanian, Universitas Brawijaya Malang pada bulan April 2010 sampai Juni 2010.

\section{Bahan dan Alat Bahan}

Bahan yang digunakan dalam penelitian ini adalah kelopak rosella (Hibiscus sabdariffa Linn.) berumur 3 bulan yang diperoleh dipetani Desa Jombor Karangmojo, Gunungkidul, Yogyakarta, madu randu yang diperoleh dari Kebun Raya Purwodadi, Kabupaten Malang dan diambil pada panen kedua sekitar
Bulan Mei-Juni serta air minum (potable drink).

Bahan kimia untuk analisis diperoleh dari CV. Panadia, PT. Dianum dan Laboratorium Biokimia dan Nutrisi Jurusan Teknologi Hasil Pertanian. Bahan kimia dengan spesifikasi p.a (pro analisis) adalah: 1) DPPH (1,1diphenyl-2-picrylhydrazyl), metanol (Merck) dan asam askorbat (Rheidel Hein) untuk analisis aktifitas penangkap radikal bebas; 2) Folin-Ciocalteu, $\mathrm{Na}_{2} \mathrm{CO}_{3}$ $7,5 \%$, asam galat semuanya dari Merck digunakan untuk analisis total fenol.

\section{Alat}

Alat-alat yang digunakan dalam penelitian ini adalah seperangkat alat pemanggang, blender kering (Panasonic) kecepatan motor pemutar pisau $1800 \mathrm{rpm}$, termometer ukuran $360^{\circ} \mathrm{C}$, pisau, baskom, panci $5 \mathrm{~L}$, kompor gas, kain saring, kain bersih dan talenan.

Alat-alat yang digunakan dalam analisis berupa timbangan digital (XP- 1500 , Jerman ), vortex (Barnstead), sentrifus (EBA 20), Gas Chromatography-Mass Spectrometry QP2010 (Shimadzu, Jepang), FTIR (Fourier Transform 
Infrared Spectrophotometer, ShimadzuJepang), spektofotometer UV-2100 (Unico), tabung reaksi (Pyrex), gelas ukur $50 \mathrm{ml}$ (Pyrex), erlenmeyer $250 \mathrm{ml}$ (Pyrex), labu ukur $100 \mathrm{ml}$ (Pyrex), pipet mikro 10-100 $\mu \mathrm{l}$ (Soccorex), pipet volum $1 \mathrm{ml}$ (Assistance), pipet volum 5 $\mathrm{ml}$ (HBG), beaker glass $250 \mathrm{ml}$ (Pyrex), corong pemisah $100 \mathrm{ml}$ (Schott-Duran), rak kayu tabung reaksi, Bubble Suck, buret, spatula, spatula panjang, Theromostirer, Magnetic Stirrer $3 \mathrm{~cm}$ dan kertas saring Whatman No. 42.

\section{Metode Penelitian}

\section{Penelitian Tahap I : Pengaruh Kondisi Bahan Baku dan Waktu Pemanasan terhadap Aktifitas Antioksidan pada Rosella}

Penelitian ini dilakukan untuk mengetahui pengaruh kombinasi perlakuan dari kondisi bahan baku dan suhu pemanasan pada rosella terhadap aktifitas antioksidan yang akan diaplikasikan pada minuman fungsional. Penelitian ini menggunakan Rancangan Acak Kelompok (RAK) dua faktor dengan variabel terikat adalah rosella kering $\left(\mathrm{K}_{1}\right)$ dan rosella segar $\left(\mathrm{K}_{2}\right)$, sedangkan variabel bebas adalah waktu (T) yang terdiri dari lima level, yaitu 0,5 , 10, 15 dan 20 menit.

Masing-masing perlakuan diulang 3 kali sehingga diperoleh 30 satuan percobaan. Perlakuan yang memiliki aktifitas antioksidan terbaik dari rosella $\left(\mathrm{X}_{\mathrm{A}}\right.$ atau $\left.\mathrm{X}_{\mathrm{B}}\right)$ dilakukan pengujian kualitas dan bioaktif yang terdiri dari kadar total antosianin, total fenolik (sebagai asam galat) dengan menggunakan metode FolinCiocalteu dan aktifitas antioksidan dengan menggunakan metode penangkap radikal bebas DPPH. Hasil terbaik dilanjutkan dengan analisis GC-MS dan FTIR serta digunakan dalam penelitian tahap II.

\section{Penelitian Tahap II: Penentuan Jumlah Konsentrasi Madu untuk Dikombinasikan dengan Ekstrak Rosella}

Jaya (2008) mengemukakan bahwa kombinasi jumlah konsentrasi madu yang dicampurkan dengan bahan lain adalah 47,316 mL, sehingga interval konsentrasi madu yang didapat menjadi $15 \mathrm{~mL}, 30 \mathrm{~mL}$ dan $45 \mathrm{~mL}$. Kombinasi antara ekstrak rosela dan madu dilarutkan dengan air yang dapat diminum (potable water) sampai $100 \mathrm{~mL}$ sebagai 
perbandingan jumlah solut terhadap jumlah larutan.

Penelitian ini menggunakan Rancangan Acak Kelompok (RAK) dua faktor dengan variabel terikat adalah kombinasi perlakuan terbaik penelitian tahap I (X), sedangkan variabel bebas adalah konsentrasi madu (M) yang terdiri dari tiga level, yaitu $15 \mathrm{~mL}, 30$ $\mathrm{mL}$ dan $45 \mathrm{~mL}$.

Setiap perlakuan diulang sebanyak empat kali sehingga terdapat 12 unit percobaan. Perlakuan yang memiliki uji organoleptik terbaik akan dilakukan pengujian kualitas dan bioaktif yang terdiri dari kadar total antosianin, total fenolik (sebagai asam galat) dengan menggunakan metode FolinCiocalteu dan aktifitas antioksidan dengan menggunakan metode penangkap radikal bebas DPPH. Analisis GC-MS dan FTIR dilakukan berdasarkan perlakuan terbaik dari uji organolpetik.

\section{Pengamatan Parameter}

Parameter pada penelitian tahap I meliputi kadar total antosianin (Fuleki et al., 1968), total fenolik (sebagai asam galat) dengan menggunakan metode
Folin-Ciocalteu (Miliauskas et al., 2004) dan aktifitas antioksidan dengan menggunakan metode penangkap radikal bebas DPPH (Yamasaki et al., 1994).

Analisis penelitian tahap II adalah uji organoleptik yang dianalisa menurut statistik nonparametrik dengan menggunakan uji Friedman (Steel and Torrie, 1989). Dilanjutkan dengan pengujian kualitas dan bioaktif yang terdiri dari kadar total antosianin, total fenolik (sebagai asam galat) dengan menggunakan metode FolinCiocalteu dan aktifitas antioksidan dengan menggunakan metode penangkap radikal bebas DPPH.

\section{Analisa Data}

Data hasil pengamatan dianalisis dengan menggunakan ANOVA metode Rancangan Acak Kelompok dan diolah dengan menggunakan "Microsoft Excel". Apabila dari hasil analisa terdapat pengaruh yang signifikan akan dilakukan uji jarak berganda Duncan dengan selang kepercayaan 1\% (Yitnosumarto, 1993). Penentuan perlakuan terbaik dengan menggunakan metode indeks efektifitas (Susrini, 
2005). Data hasil uji organoleptik menggunakan uji Friedman (Steel dianalisa menurut statistik and Torrie, 1989).

nonparametrik dengan

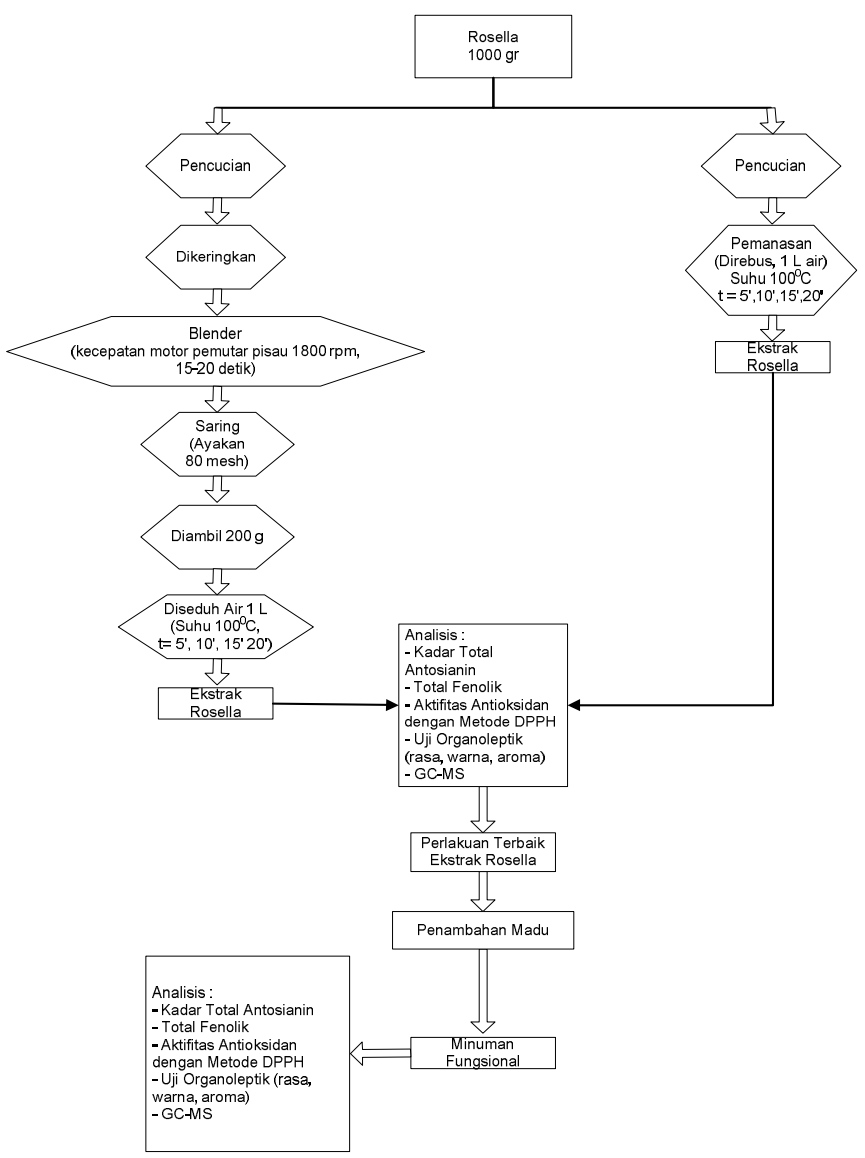

Gambar 1. Diagram Penelitian secara Menyeluruh Penelitian secara Menyeluruh 
Jurnal Teknologi Pangan Vol.3 No.1

Juni 2012

HASIL DAN PEMBAHASAN

PenelitianTahap I: Pengaruh Kondisi BahanBaku dan Waktu Pemanasan terhadap Aktifitas Antioksidan pada Rosella

\section{Aktifitas Penangkap Radikal} Bebas

Aktifitas penangkap radikal bebas yang diperoleh pada penelitian tahap I menggunakan metode DPPH berkisar antara 58,83 - 75,59\%. Rerata nilai aktifitas penangkap radikal bebas kelopak rosella pada berbagai kombinasi perlakuan ditunjukkan pada Tabel 1.

Tabel 1. Rerata Aktifitas Penangkap Radikal Bebas (\%) dari Kondisi Bahan Baku Akibat Perbedaan Waktu Pemanasan

\begin{tabular}{|c|c|c|c|}
\hline $\begin{array}{c}\text { Kondisi Bahan } \\
\text { Baku }\end{array}$ & $\begin{array}{c}\text { Waktu } \\
\text { (menit) }\end{array}$ & $\begin{array}{c}\text { Rerata Aktifitas } \\
\text { Penangkap Radikal } \\
\text { Bebas (\%) }\end{array}$ & $\begin{array}{c}\text { DMRT } \\
(\boldsymbol{\alpha}=\mathbf{0 , 0 1})\end{array}$ \\
\hline \multirow{3}{*}{ Kering } & 5 & $58,83 \pm 0,09 \mathrm{a}$ & - \\
\cline { 2 - 4 } & 10 & $75,59 \pm 0,38 \mathrm{f}$ & 1,28 \\
\cline { 2 - 4 } & 15 & $69,43 \pm 0,43 \mathrm{~d}$ & 1,25 \\
\cline { 2 - 4 } & 20 & $74,07 \pm 0,55 \mathrm{e}$ & 1,28 \\
\hline \multirow{3}{*}{ Segar } & 5 & $60,35 \pm 0,16 \mathrm{~b}$ & 1,14 \\
\cline { 2 - 4 } & 10 & $66,46 \pm 0,18 \mathrm{c}$ & 1,23 \\
\cline { 2 - 4 } & 15 & $69,77 \pm 0,52 \mathrm{~d}$ & 1,27 \\
\hline
\end{tabular}

Keterangan: Angka rerata yang diikuti dengan huruf yang sama pada kolom yang sama tidak berbeda nyata pada uji Duncan $1 \%$

Data dalam Tabel 1 menunjukkan uji DMRT $(\alpha=0,01)$ kombinasi perlakuan terbaik aktifitas penangkap radikal bebas diperoleh dari kelopak rosella kering yang dipanaskan selama 10 menit dan sangat berbeda nyata dengan yang lain, yaitu sebesar 
$75,59 \pm 0,38 \%$. Sedangkan nilai terkecil didapatkan pada kelopak rosella kering yang dipanasan selama 5 menit, yaitu sebesar $58,83 \pm 0,09 \%$.

Peningkatan aktifitas penangkap radikal radikal bebas dikarenakan daya larut komponen aktif dimungkinkan meningkat karena dinding sel yang rusak akibat terjadinya pemanasan. Pernyataan ini diperkuat oleh Khatun et al. (2006) yang menyatakan bahwa perlakuan pemanasan memungkinkan untuk merusak dinding sel dan subseluler dari tanaman herbal untuk membebaskan komponen aktif dalam jumlah yang besar sehingga menghasilkan komponen penangkap radikal bebas yang kuat.

\section{Total Fenol}

Total fenol yang diperoleh pada penelitian tahap I berkisar antara $\quad 5,046-6,491 \mathrm{mg} / \mathrm{g}$. Rerata nilai total fenol kelopak rosella pada berbagai kombinasi perlakuan ditunjukkan pada Tabel2.

Data dalam Tabel 2 menunjukkan uji DMRT $(\alpha=0,01)$ kombinasi perlakuan terbaik total fenol diperoleh dari kelopak rosella kering yang dipanaskan selama 10 menit dan sangat berbeda nyata dengan yang lain, yaitu sebesar $6,491 \pm 0,34 \mathrm{mg} / \mathrm{g}$. Sedangkan nilai terkecil didapatkan pada kelopak rosella kering yang dipanasan selama 5 menit, yaitu sebesar 5,046 $\pm 0,74$ $\mathrm{mg} / \mathrm{g}$. 
Jurnal Teknologi Pangan Vol.3 No.1

Juni 2012

Tabel 2. Rerata Total Fenol (mg/g) dari Kelopak Rosella Akibat Perbedaan Waktu Pemanasan

\begin{tabular}{|c|c|c|c|}
\hline $\begin{array}{c}\text { Kondisi Bahan } \\
\text { Baku }\end{array}$ & $\begin{array}{c}\text { Waktu } \\
\text { (menit) }\end{array}$ & $\begin{array}{c}\text { Rerata Total } \\
\text { Fenol }(\mathbf{m g} / \mathbf{g})\end{array}$ & $\begin{array}{c}\text { DMRT } \\
(\boldsymbol{\alpha}=\mathbf{0 , 0 1})\end{array}$ \\
\hline \multirow{4}{*}{ Kering } & 5 & $5,046 \pm 0,74 \mathrm{a}$ & - \\
\cline { 2 - 4 } & 10 & $6,491 \pm 0,34 \mathrm{f}$ & 0,118 \\
\cline { 2 - 4 } & 15 & $6,196 \pm 0,62 \mathrm{~d}$ & 0,115 \\
\cline { 2 - 4 } & 20 & $5,718 \pm 0,33 \mathrm{c}$ & 0,113 \\
\hline \multirow{4}{*}{ Segar } & 5 & $5,353 \pm 0,70 \mathrm{~b}$ & 0,105 \\
\cline { 2 - 4 } & 10 & $\begin{array}{l}5,692 \pm 0,26 \\
\text { bc }\end{array}$ & 0,110 \\
\cline { 2 - 4 } & 15 & $6,337 \pm 0,92 \mathrm{e}$ & 0,116 \\
\cline { 2 - 4 } & 20 & $6,474 \pm 0,18 \mathrm{f}$ & 0,117 \\
\hline
\end{tabular}

Keterangan : Angka rerata yang diikuti dengan huruf yang sama pada kolom yang sama tidak berbeda nyata pada uji Duncan $1 \%$

Data dalam Tabel 2 ini dikarenakan terjadinya menunjukkan uji DMRT $(\alpha=0,01)$ hidrolisis pada glikosida menjadi kombinasi perlakuan terbaik total fenol diperoleh dari kelopak rosella kering yang dipanaskan selama 10 menit dan sangat berbeda nyata dengan yang lain, yaitu sebesar 6,491 $\pm 0,34 \%$. Sedangkan nilai terkecil didapatkan pada kelopak rosella kering yang dipanasan selama 5 menit, yaitu sebesar 5,046 $\pm 0,74 \%$.

Total fenol pada kelopak rosella kering dengan pemanasan menit ke-5 mengalami peningkatan saat dipanaskan pada menit ke-10. Menurut Khatun et al. (2006), hal aglikon. Flavonoid yang berada didalam sel sebagai glikosida dapat rusak akibat adanya enzim, asam maupun perlakuan pemanasan, sehingga membentuk aglikon dan gula. Aglikon dikenal memiliki potensi sebagai antioksidan daripada glikosida sehingga sangat dimungkinkan aktifitas antioksidan dapat meningkat setelah perlakuan pemanasan.

Fungsi utama dari antioksidan yaitu sebagai pemberi atom hidrogen. Antioksidan (AH) yang mempunyai fungsi utama tersebut 
sering disebut sebagai antioksidan primer. Senyawa ini dapat memberikan atom hidrogen secara cepat ke radikal lipida ( $\left.\mathrm{R}^{*}, \mathrm{ROO}^{*}\right)$ atau mengubahnya ke bentuk lebih stabil, sementara turunan radikal antioksidan $\left(\mathrm{A}^{*}\right)$ tersebut memiliki keadaan lebih stabil dibanding radikal lipida. Reaksi antioksidan sebagai pemberi hidrogen pada radikal bebas disajikan pada Gambar 2

$$
\text { Inisiasi } \quad: \mathrm{R}^{*}+\mathrm{AH} \underset{\substack{\text { Radikal lipida } \\-}}{\mathrm{R}}+\mathrm{A}^{*}
$$$$
\text { Propagasi : } \mathrm{ROO}^{*}+\mathrm{AH}
$$$$
\mathrm{ROOH}+\mathrm{A}^{*}
$$

Radikal Peroksi

\section{Gambar 2. Reaksi Antioksidan (AH) sebagai Pemberi Hidrogen pada Radikal Bebas}

\section{Total Antosianin}

Total antosianin yang diperoleh pada penelitian tahap I berkisar antara - $\mathrm{mg} / \mathrm{g}$. Rerata nilai total antosianin terhadap kondisi vahan baku kelopak rosella ditunjukkan pada Tabel 3 .

Tabel 3. Rerata Pengaruh Kondisi Bahan Baku Rosella terhadap Total Antosianin (mg/g) dari Kelopak Rosella

\begin{tabular}{|l|c|c|}
\hline \multicolumn{1}{|c|}{ Kondisi Rosella } & Rerata Total Antosianin (mg/g) & \multirow{2}{*}{ BNT 1\% } \\
\cline { 1 - 2 } Kering & $7,074 \mathrm{a}$ & \multirow{2}{*}{0,226} \\
\hline Basah & $17,135 \mathrm{~b}$ & \\
\hline
\end{tabular}

Keterangan : Angka rerata yang diikuti dengan huruf yang sama pada kolom yang sama tidak berbeda nyata pada BNT $1 \%$ 
Data dalam Tabel 3 diolah. Hal ini dikarenakan menunjukkan bahwa total antosianin rentan terhadap proses antosianin tertinggi diperoleh dari pemanasan, sehingga akan kondisi rosella yang kering. Total menurunkan total antosianin. antosianin tertinggi pada kondisi Sedangkan rerata nilai total rosella basah. Tsai (2001) antosianin terhadap lama menjelaskan bahwa rosella segar pemanasan pada kelopak rosella memiliki antosianin yang lebih ditunjukkan pada Tabel 4. tinggi daripada rosella yang telah

Tabel 4. Rerata Pengaruh Lama Pemanasan terhadap Total Antosianin (mg/g) dari Kelopak Rosella

\begin{tabular}{|c|c|c|}
\hline $\begin{array}{c}\text { Lama Pemanasan } \\
\text { (Menit) }\end{array}$ & Rerata Total Antosianin (mg/g) & \multirow{2}{*}{ BNT 1\% } \\
\hline 5 & $8,048 \mathrm{a}$ & \multirow{2}{*}{0,266} \\
\hline 10 & $8,355 \mathrm{~b}$ & \\
\hline 15 & $9,569 \mathrm{c}$ & \\
\hline 20 & $9,595 \mathrm{c}$ & \\
\hline
\end{tabular}

Keterangan : Angka rerata yang diikuti dengan huruf yang sama pada kolom yang sama tidak berbeda nyata pada BNT $1 \%$

Data dalam Tabel 4 menunjukkan bahwa total antosianin tertinggi diperoleh dari lama pemanasan selama 20 menit. Total antosianin meningkat dengan semakin lamanya pemanasan. Semakin lama pemanasan maka akan menyebabkan komponen antosianin bertambah dan meningkat. Hal ini sesuai dengan pernyataan Mazza and Miniati
(1993) menyatakan bahwa perlakuan pemanasan memungkinkan untuk merusak dinding sel dan subseluler dari kelopak rosella untuk membebaskan komponen aktif dalam jumlah yang besar sehingga menghasilkan komponen antosianin yang tinggi. 
Pemilihan Perlakuan Terbaik Parameter tersebut terdiri dari Tahap I analisis aktifitas penangkap radikal

Penentuan perlakuan terbaik bebas, total fenol dan total perlakuan bahan baku kelopak antosianin. Perhitungan untuk rosella terhadap waktu pemanasan penentuan perlakuan terbaik pada penelitian tahap I dilakukan kondisi kelopak rosella dengan menggunakan metode berdasarkan waktu pemanasan dan indeks efektifitas (Susrini, 2005). hasil penilaian perlakuan terbaik Metode ini dilakukan pada disajikan pada Tabel 5. parameter aktifitas antioksidan.

Tabel 5. Penilaian Perlakuan Terbaik terhadap Parameter Aktifitas Antioksidan pada Kombinasi Perlakuan Kondisi Kelopak Rosella terhadap Lama Pemanasan

\begin{tabular}{|c|c|c|}
\hline \multirow{2}{*}{ Kondisi Bahan Baku } & Waktu (menit) & Skor \\
\hline \multirow{3}{*}{ Kering } & 5 & 0,300 \\
\cline { 2 - 3 } & 10 & $0704 *$ \\
\cline { 2 - 3 } & 15 & 0,511 \\
\cline { 2 - 3 } & 20 & 0,435 \\
\hline \multirow{3}{*}{ Segar } & 5 & 0,291 \\
\cline { 2 - 3 } & 10 & 0,646 \\
\cline { 2 - 3 } & 15 & 0,506 \\
\cline { 2 - 3 } & 20 & 0,408 \\
\hline
\end{tabular}

$*$ = perlakuan terbaik

Data dalam Tabel 5 kombinasi perlakuan kelopak menunjukkan bahwa kombinasi rosella kering yang dipanaskan perlakuan terbaik pada tahap I selama 10 menit. Parameter untuk parameter aktifitas aktifitas antioksidan pada antioksidan dari perlakuan kondisi perlakuan terbaik tahap I adalah: bahan baku terhadap waktu kemampuan kelopak rosella untuk pemanasan diperoleh dari menangkap radikal bebas $\mathrm{DPPH}^{-}$ 
sebesar $75,59 \pm 0,38 \%$, total fenol

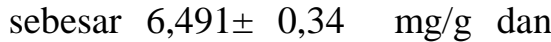
total antosianin sebesar 3,862 \pm $0,18 \mathrm{mg} / \mathrm{g}$.

\section{Analisis Senyawa Antioksidan} pada Perlakuan Terbaik Tahap I

Komponen antioksidan dari kelopak rosella kering pada menit ke-10 diidentifikasi dengan GCMS untuk mengidentifikasi senyawa antioksidan dan FTIR untuk memberi ciri komposisi analitis bahan.

Analisis Senyawa Antioksidan Perlakuan Terbaik Tahap I Menggunakan GC-MS

Kromatogram GC-MS dan senyawa-senyawa hasil identifikasi GC-MS dari kelopak rosella kering yang dipanaskan pada menit ke-10 disajikan pada Gambar 3.
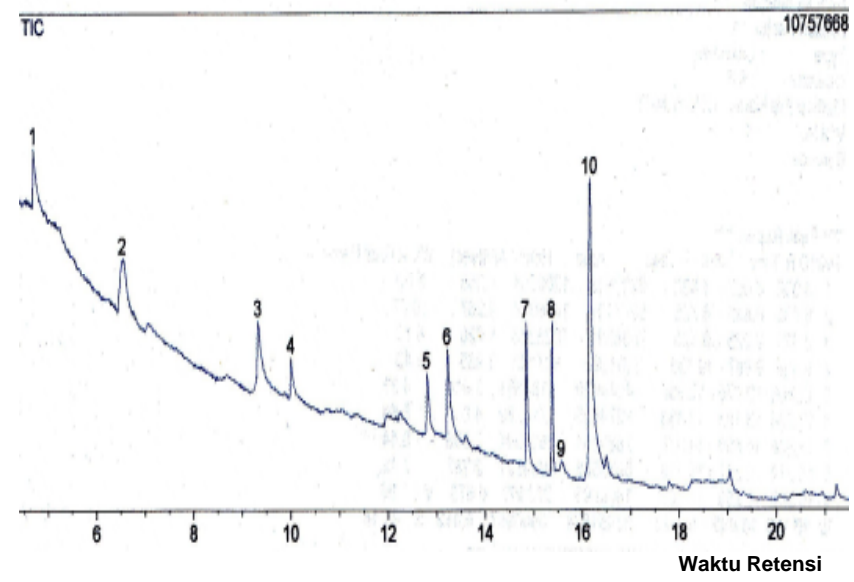

Gambar 3. Kromatogram GC-MS Kelopak Rosella Kering yang Dipanaskan selama 10 Menit 
Gambar 3 menunjukkan hasil respon detektor GC-MS, bahwa senyawa yang paling dominan dari kelopak rosella kering yang dipanaskan pada menit ke-10 adalah hydroxy methyl furfurole pada puncak nomor 10 (41,14\%), furfural pada puncak nomor 2 $(10,67 \%), \quad 4$ H-pyran-4-one,2,3 dihydro 3,5 dihydroxy 6 methyl pada puncak nomor $6(8,86 \%)$, 5methyl-furfural pada puncak nomor $3(8,13 \%)$, dan dodecanal pada puncak nomor $8(7,42 \%)$. Berikut disajikan produk senyawa kelopak rosella kering hasil perebusan selama 10 menit pada Tabel 6.

Tabel 6. Produk Senyawa Kelopak Rosella Kering Hasil Pemanasan selama 10 Menit

\begin{tabular}{|c|c|c|c|}
\hline $\begin{array}{c}\text { No. } \\
\text { Puncak }\end{array}$ & $\begin{array}{c}\text { Senyawa yang } \\
\text { Muncul }\end{array}$ & Nama IUPAC & $\begin{array}{c}\text { Golongan } \\
\text { Senyawa }\end{array}$ \\
\hline 1 & Acetil acid & Ethanoic acid & $\begin{array}{l}\text { Asam } \\
\text { Karboksilat }\end{array}$ \\
\hline 2 & Furfural & Furan-2-carbaldehyde & $\begin{array}{l}\text { Aromatik } \\
\text { aldehid }\end{array}$ \\
\hline 3 & 5-methyl-furfural & $\begin{array}{l}\text { 5-methylfuran-2- } \\
\text { carbaldehyde }\end{array}$ & Keton \\
\hline 4 & 2(5H)-furanone & $\begin{array}{l}\text { 4-ethenyl-2-hydroxy- } \\
\text { 2H-furan-5-one }\end{array}$ & Keton \\
\hline 5 & - & & \\
\hline 6 & $\begin{array}{l}\text { 4H-pyran-4-one, } 2,3 \\
\text { dihydro } 3,5 \\
\text { dihydroxy } 6 \text { methyl } \\
\text { - }\end{array}$ & $\begin{array}{l}\text { 3,5-dihydroxy-6- } \\
\text { methyl-2,3- } \\
\text { dihydropyran-4-one }\end{array}$ & Aldehid \\
\hline 8 & Dodecanal & Dodecanal & \\
\hline $\begin{array}{c}9 \\
10\end{array}$ & $\begin{array}{l}\text { Isoamyl propionate } \\
\text { Hydroxy methyl } \\
\text { furfurole }\end{array}$ & $\begin{array}{l}\text { Isoamyl propionate } \\
\text { 5-(hydroxymethyl)-2- } \\
\text { furaldehyde }\end{array}$ & Furfural \\
\hline
\end{tabular}

Keterangan :

-SI (Identifikasi Similaritas) $<80$ tidak dapat diidentifikasi dari database 
Jurnal Teknologi Pangan Vol.3 No.1

Juni 2012

Analisis Gugus Fungsional selama 10 menit tidak berbeda Perlakuan Terbaik Tahap I dengan kelopak rosella segar tanpa Menggunakan Fourier pemanasan. Sebanyak 22 gugus Transform Infra Red (FTIR) fungsional yang teridentifikasi Spektofotometri

Kromatogram FTIR dari $\left(-\mathrm{CH}_{2} \mathrm{OH}\right)$, eter (R-O-R), ester kelopak rosella kering yang (RCOOR), alkana metil $-\mathrm{CH}_{3^{-}}$, dipanaskan selama 10 menit $\mathrm{C}=\mathrm{C}$ aromatik, alkena vinil disajikan pada Gambar 4. Sebagian $\quad\left(-\mathrm{CH}_{2}=\mathrm{CH}_{2}\right)$, asam karboksilat besar gugus fungsi dari kelopak $(\mathrm{RCOOH})$ dan gugus $\mathrm{OH}$.

rosella kering yang dipanaskan

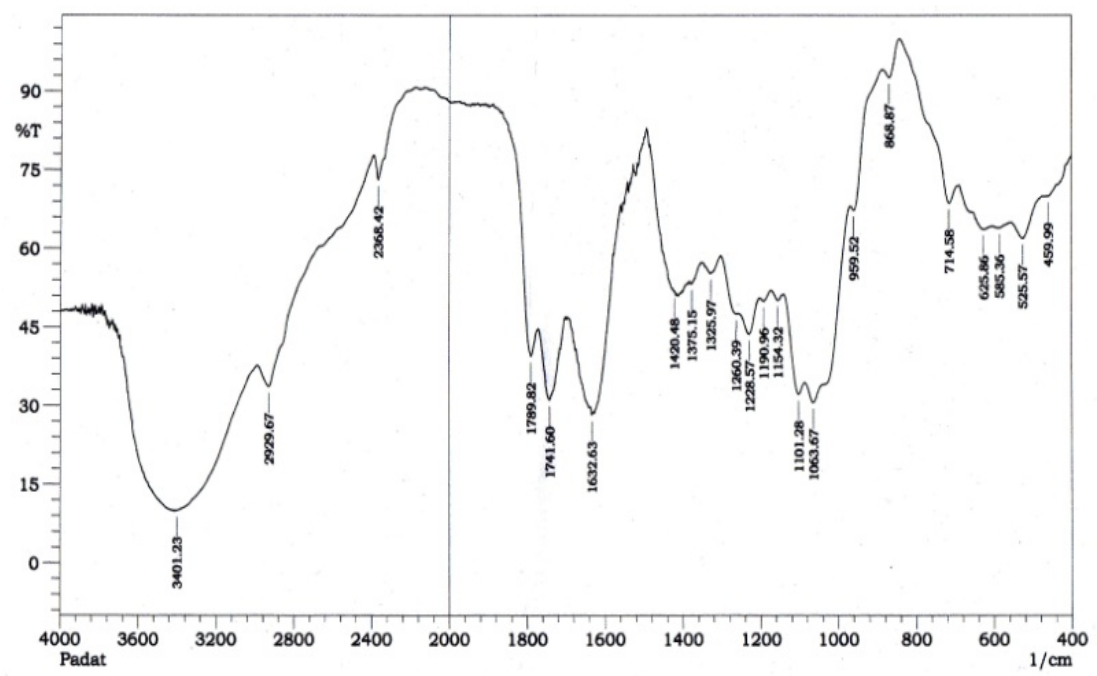

Gambar 4. Spektrum Inframerah Kelopak Rosella Kering yang
Dipanaskan selama 10 Menit 
Gambar 4 menunjukkan spektrum inframerah dari kelopak rosella kering yang dipanaskan selama 10 menit, dimana memberikan serapan yang paling dominan pada bilangan gelombang $3401,23 \mathrm{~cm}^{-1}$ (kuat lebar) yang khas untuk regangan gugus $\mathrm{OH}$, bilangan gelombang $1632,63 \mathrm{~cm}^{-1}$ khas untuk gugus keton (R-CO-R) dan bilangan gelombang 1741,6 $\mathrm{cm}^{-1}$ (kuat tajam) khas untuk regangan asam karboksilat $(\mathrm{RCOOH})$. Gugus fungsional dari kelopak rosella kering yang dipanaskan selama 10 menit disajikan pada Tabel 7.

Tabel 7.Analisis Gugus Fungsional Ekstrak Kelopak Rosella yang Dipanaskan selama 10 Menit Menggunakan Fourier Transform Infra Red (FTIR)

\begin{tabular}{|l|c|l|l|}
\hline No & $\begin{array}{c}\text { Bilangan Gelombang } \\
\left(\mathbf{c m}^{-1}\right)\end{array}$ & \multicolumn{1}{|c|}{ Jenis Vibrasi } & \multicolumn{1}{|c|}{ Gugus Fungsi } \\
\hline 1 & 459,99 & C-OH bend & Fenol \\
2 & 525,57 & Def. cincin $(2 \mathrm{p})$ & Aromatik \\
3 & 585,36 & Def. cincin $(2 \mathrm{p})$ & Aromatik \\
4 & 625,86 & O-C-O bend & Ester (RCOOR) \\
5 & 714,58 & CH bend kel. bid. & Aromatik \\
6 & 868,87 & CH bend kel. bid. & Aromatik \\
7 & 959,52 & C-C stretch & Alifatik \\
8 & 1063,67 & C-OH stretch & Alkohol (-CH $\left.{ }_{2} \mathrm{OH}\right)$ \\
9 & 1101,28 & C-OH stretch & Alkohol (-CHROH) \\
10 & 1154,32 & - & - \\
11 & 1190,96 & C-O-C stretch vinil eter & Eter (R-O-R) \\
12 & 1228,57 & C-O-C stretch alkil-aril eter & Eter (R-O-R) \\
13 & 1260,39 & C-O-C stretch alkil-aril eter & Eter (R-O-R) \\
14 & 1325,97 & H-C=O bend. Alifatik aldehid & Aldehida (R-CHO) \\
15 & 1375,15 & H-C=O bend. Alifatik aldehid & Aldehida (R-CHO) \\
16 & 1420,48 & H-C=O bend. Alifatik aldehid & Aldehida (R-CHO) \\
17 & 1632,63 & C=C stretch konj. & Keton (R-CO-R) \\
18 & 1741,6 & C=O stretch monomer, dil. sol & Asam Karboksilat (RCOOH) \\
19 & 1789,82 & C=O stretch monomer, dil. sol & Asam Karboksilat (RCOOH) \\
20 & 2368,42 & - & - \\
21 & 2929,67 & CH stretch dalam C-CH ${ }_{3}$ & Alkana (Metil -CH $\left.{ }_{3}^{-}\right)$ \\
22 & 3401,23 & OH stretch H bonded & OH \\
\hline
\end{tabular}


Penelitian Tahap II : Penentuan Jumlah Konsentrasi Madu untuk Dikombinasikan dengan Ekstrak Kelopak Rosella Kering

Penelitian mengkombinasikan terbaik pada Tahap I dengan konsentrasi madu 15\%, 30\% dan $45 \%$ (v/v). Adapun parameter yang diamati pada tahap II meliputi aktifitas penangkap radikal bebas, total fenol dan total fenolik.

\section{Aktifitas Penangkap Radikal} Bebas

Rerata aktifitas penangkap radikal bebas pada berbagai kombinasi perlakuan kelopak rosella kering 10 menit dengan konsentrasi madu yang dihasilkan berkisar antara 30,23-35,73\%. Rerata nilai aktifitas penangkap radikal bebas pada berbagai kombinasi perlakuan ditunjukkan pada Tabel 8.

Tabel 8. Rerata Aktifitas Penangkap Radikal Bebas (\%) pada Berbagai Kombinasi Perlakuan Konsentrasi Madu Randu $(\% \mathrm{v} / \mathrm{v})$

\begin{tabular}{|c|c|c|}
\hline $\begin{array}{c}\text { Ekstrak Kelopak } \\
\text { Rosella }\end{array}$ & $\begin{array}{c}\text { Konsentrasi } \\
\text { Madu (\% v/v) }\end{array}$ & $\begin{array}{c}\text { Rerata } \\
\text { Aktifitas Penangkap } \\
\text { Radikal Bebas (\%) }\end{array}$ \\
\hline $\begin{array}{c}\text { Dipanaskan selama 10 } \\
\text { menit }\end{array}$ & 15 & $30,23 \pm 0,27 \mathrm{a}$ \\
\cline { 2 - 3 } & 30 & $33,65 \pm 012 \mathrm{~b}$ \\
\cline { 2 - 3 } & 45 & $35,73 \pm 034 \mathrm{c}$ \\
\hline
\end{tabular}

Data dalam Tabel 8 dengan konsentrasi madu $45 \%$ menunjukkan bahwa semakin sebesar 35,73 $\pm 0,34 \%$ dan meningkat proporsi madu randu terendah pada kombinasi kelopak maka semakin meningkat pula aktifitas penangkap radikal bebas minuman fungsional. Rerata rosella kering yang dipanaskan selama 10 menit dengan aktifitas penangkap radikal bebas tertinggi didapatkan dari kombinasi ekstrak kelopak rosella kering yang dipanaskan selama 10 menit konsentrasi madu $15 \%$ sebesar $30,23 \pm 0,27 \%$. Persentase penangkap radikal bebas minuman fungsional lebih kecil dibandingkan dengan kelopak rosella dengan atau 
tanpa pemanasan (> 60\%). materi lain maka dimungkinkan Penurunan ini dapat disebabkan salah satu materi itu saling karena adanya kombinasi dua bahan melengkapi untuk memberikan baku dalam satu larutan (madu dan perlindungan yang terbaik.

ekstrak kelopak rosella kering). Kruawan and Kangsadalampain (2006) menjelaskan bahwa sinergisitas karakteristik komponen suatu bahan dimungkinkan akan hilang dalam bentuk campuran dengan bahan lain.

Weiner (1994) menjelaskan lebih lanjut bahwa apabila komponen antioksidan suatu materi dikombinasikan dengan

\section{Total Fenol}

Rerata total fenol dari kombinasi ekstrak kelopak rosella kering 10 menit dengan konsentrasi madu yang dihasilkan berkisar antara $0,59-1,03 \mathrm{mg} / \mathrm{g}$. Rerata nilai total fenol (mg/g) pada berbagai kombinasi perlakuan ditunjukkan pada Tabel 9.

Tabel 9. Rerata Total Fenol (mg/g) pada Berbagai Kombinasi Perlakuan Konsentrasi Madu Randu (\% v/v)

\begin{tabular}{|c|c|c|}
\hline $\begin{array}{c}\text { Ekstrak Kelopak } \\
\text { Rosella }\end{array}$ & $\begin{array}{c}\text { Konsentrasi Madu } \\
(\boldsymbol{\%} \mathbf{~ v / v})\end{array}$ & $\begin{array}{c}\text { Rerata Total Fenol } \\
(\mathbf{m g} / \mathbf{g})\end{array}$ \\
\hline \multirow{2}{*}{$\begin{array}{c}\text { Dipanaskan selama } \\
10 \text { menit }\end{array}$} & 15 & $0,59 \pm 0,54 \mathrm{a}$ \\
\cline { 2 - 3 } & 30 & $0,72 \pm 0,9 \mathrm{~b}$ \\
\cline { 2 - 3 } & 45 & $1,03 \pm 0,3 \mathrm{c}$ \\
\hline
\end{tabular}

Data dalam Tabel 9 menunjukkan bahwa semakin meningkat proporsi madu randu maka semakin meningkat pula total fenol minuman fungsional. Rerata total fenol tertinggi didapatkan dari kombinasi esktrak rosella kering yang dipanaskan selama 10 menit dengan konsentrasi madu $45 \%$ sebesar $1,03 \pm 0,3 \mathrm{mg} / \mathrm{g}$ dan terendah pada esktrak rosella kering yang dipanaskan selama 10 menit dengan konsentrasi madu $15 \%$ sebesar $0,59 \pm 0,54 \mathrm{mg} / \mathrm{g}$. Schramm and Keen (2005) menjelaskan mengenai hasil penelitiannya dalam pembuatan sirup jagung yang memiliki total 
fenol sebesar $0,21 \mathrm{mg} / \mathrm{g}$. terbentuknya oksigen singlet. Penambahan madu dalam sirup Senyawa fenol sangat bagus dapat meningkatkan total fenol sebagai antioksidan karena $(\mathrm{p}<0,05) \quad$ sehingga dapat meningkatkan kemampuan plasma sebagai penangkap radikal bebas (TRAP; $\quad \mathrm{p}<0,05$ ). Hal ini mengindikasikan bahwa senyawa fenol dari madu dapat berperan sebagai antioksidan untuk melindungi tubuh dari serangan radikal bebas.

Menurut Kumalaningsih (2006), komponen senyawa fenol bersifat polar dan memilki fungsi antara lain sebagai penangkap radikal bebas dan peredam memiliki aroma dan rasa yang menyegarkan.

\section{Total Antosinin}

Rerata total antosianin dari kombinasi ekstrak kelopak rosella kering yang dipanaskan 10 menit dengan konsentrasi madu yang dihasilkan berkisar antara 1,24$2,28 \mathrm{mg} / \mathrm{g}$. Rerata nilai total antosianin pada berbagai kombinasi perlakuan ditunjukkan pada Tabel 10 .

Tabel 10. Rerata Total Antosianin (mg/g) pada Berbagai Kombinasi Perlakuan Kosentrasi Madu Randu (\% v/v)

\begin{tabular}{|c|c|c|}
\hline $\begin{array}{c}\text { Ekstrak Kelopak } \\
\text { Rosella }\end{array}$ & $\begin{array}{c}\text { Konsentrasi Madu } \\
(\boldsymbol{\%} \mathbf{~ v / v})\end{array}$ & $\begin{array}{c}\text { Rerata Total } \\
\text { Antosianin }(\mathbf{m g} / \mathbf{g})\end{array}$ \\
\hline \multirow{2}{*}{$\begin{array}{c}\text { Dipanaskan selama } \\
10 \text { menit }\end{array}$} & 15 & $1,24 \pm 0,29 \mathrm{a}$ \\
\cline { 2 - 3 } & 30 & $1,82 \pm 0,51 \mathrm{~b}$ \\
\cline { 2 - 3 } & 45 & $2,28 \pm 0,43 \mathrm{c}$ \\
\hline
\end{tabular}

Data dalam Tabel 10 didapatkan dari kombinasi ekstrak menunjukkan bahwa semakin kelopak rosella kering yang meningkat proporsi madu randu dipanaskan 10 menit dengan maka semakin meningkat pula total konsentrasi madu $45 \%$ sebesar antosianin minuman fungsional. 2,28 $\pm 0,43 \mathrm{mg} / \mathrm{g}$ dan terendah Rerata total antosianin tertinggi pada kombinasi ekstrak kelopak 
rosella kering yang dipanaskan 10 menit dengan konsentrasi madu $15 \%$ sebesar $1,24 \pm 0,29 \mathrm{mg} / \mathrm{g}$.

Penelitian Tahap III Uji Organoleptik

Rasa

\section{Hasil uji organoleptik} menunjukkan bahwa rerata ranking kesukaan panelis terhadap rasa dari ekstrak kelopak rosella kering yang dipanaskan 10 menit dengan konsentrasi madu $(15 \%, 30 \%$ dan $45 \%)$ berkisar antara 5,1 - 7,65 (Lampiran). Rerata ranking tingkat kesukaan panelis terhadap rasa ketiga konsentrasi madu ditunjukkan pada Gambar 5.

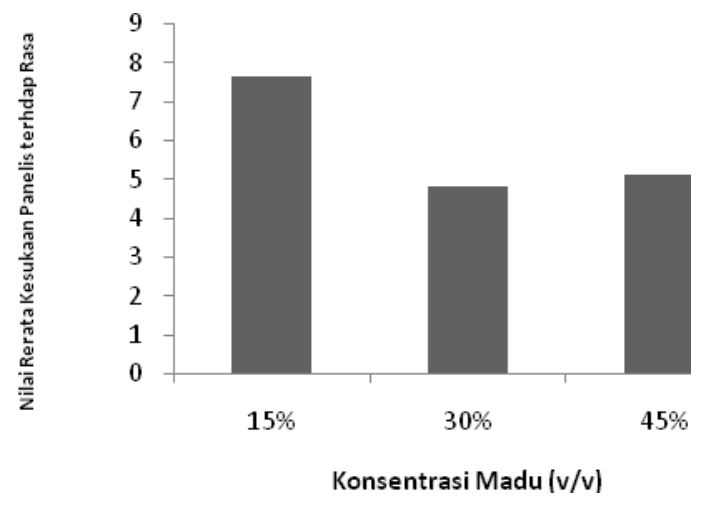

\section{Gambar 5. Rerata Kesukaan Panelis terhadap Rasa Minuman Fungsional Rosella Madu}

Gambar 5 menunjukkan konsentrasi madu 30\%. Sedangkan rerata nilai kesukaan panelis nilai tertinggi sebesar 7,65 terhadap rasa pada dari ketiga didapatkan dari konsentrasi madu konsentrasi madu, didapatkan $15 \%$.

nilai terendah sebesar 4,8 dari 
Hasil analisis Uji Friedman $(\alpha=0,05)$ menunjukkan bahwa uji perbandingan pada tiga konsentrasi madu memberikan pengaruh nyata terhadap rerata kesukaan rasa madu. Kombinasi perlakuan terbaik tingkat kesukaan rasa diperoleh dari konsentrasi madu $15 \%$, dimana sebagian besar panelis menyukai asam manis dan rasa manis dari madu. Fischer and Scott (1997) dalam Wartini (2007) menjelaskan bahwa flavor diklasifikasikan menjadi tiga, yaitu sensasi rasa (taste), trigeminal dan aroma (odour). sedangkan sensasi aroma dihasilkan oleh senyawa volatil.

Rasa manis pada minuman fungsional berasal dari fruktosa pada madu. Menurut Bogdanov et al. (2004), satu hal yang harus dipastikan bahwa madu harus dalam keadaan alami dan tanpa perlakuan pemanasan dan HMF harus dibawah nilai $15 \mathrm{mg} / \mathrm{kg}$. HMF merupakan senyawa yang dihasilkan dari penguraian gula seperti glukosa atau fruktosa pada pH 5 atau kurang.

\section{Warna}

Hasil uji organoleptik menunjukkan bahwa rerata ranking kesukaan panelis terhadap warna dari ekstrak kelopak rosella kering yang dipanaskan 10 menit dengan konsentrasi madu (15\%, $30 \%$ dan $45 \%$ ) berkisar antara 3,96 $-6,04$ (Lampiran). Semakin tinggi rerata ranking kesukaan panelis, maka tingkat kesukaan panelis terhadap warna ketiga konsentrasi madu semakin besar. Rerata ranking tingkat kesukaan panelis terhadap warna ketiga konsentrasi madu ditunjukkan pada Gambar 6. 


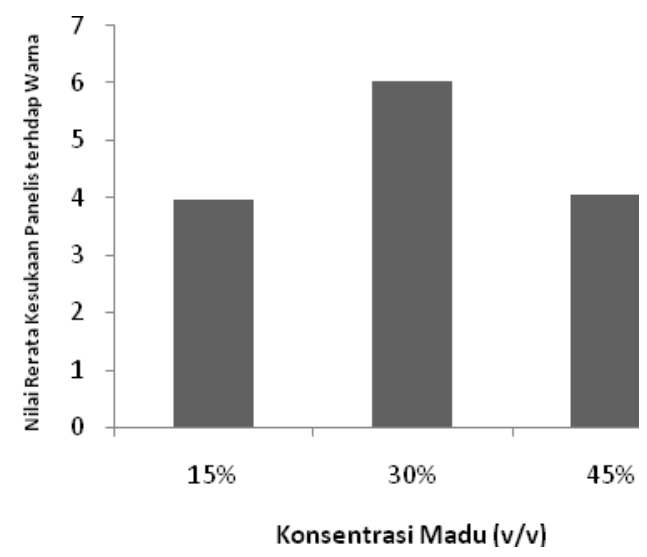

\section{Gambar 6. Rerata Kesukaan Panelis terhadap Warna Minuman Fungsional Rosella Madu}

Gambar 6 menunjukkan rerata nilai kesukaan panelis terhadap warna dari ketiga konsentrasi madu, didapatkan nilai terendah sebesar 3,96 dari konsentrasi madu $15 \%$. Sedangkan nilai tertinggi sebesar 6,04 didapatkan dari konsentrasi madu $30 \%$.

Hasil analisis Uji Friedman $(\alpha=0,05)$ menunjukkan bahwa uji perbandingan pada tiga konsentrasi madu memberikan pengaruh nyata terhadap rerata kesukaan warna madu. Kombinasi perlakuan terbaik tingkat kesukaan warna diperoleh dari konsentrasi madu $30 \%$, dimana sebagian besar panelis sangat menyukai warna minuman yang merah kekuningkuningan.

Warna merah kekuningkuningan pada minuman fungsional rosella madu yang disukai oleh panelis berasal dari antosianin rosella. Tsai, McIntosh, Pearce, Camden, Jordan (2001) mengemukakan bahwa warna merah dari rosella berasal dari senyawa delphinidin 3- 
sambubioside $\quad(85 \%$ dari $(15 \%, 30 \%$ dan $45 \%)$ berkisar antosianin) dengan menggunakan antara 5,05-7,4. Semakin tinggi HPLC. rerata ranking kesukaan panelis, maka tingkat kesukaan panelis

\section{Aroma} terhadap aroma ketiga konsentrasi Hasil uji organoleptik madu semakin besar. Rerata menunjukkan bahwa rerata ranking ranking tingkat kesukaan panelis kesukaan panelis terhadap aroma terhadap aroma ketiga konsentrasi dari kombinasi ekstrak kelopak madu ditunjukkan pada Gambar 7. rosella kering yang dipanaskan 10 menit dengan konsentrasi madu

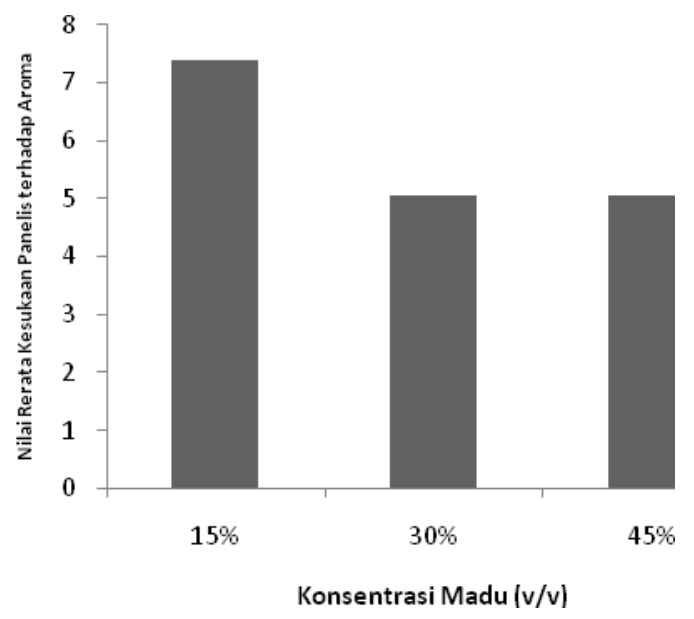

Gambar 7. Rerata Kesukaan Panelis terhadap Aroma Minuman Fungsional Rosella Madu 
Gambar 7 menunjukkan rerata nilai kesukaan panelis terhadap aroma dari ketiga konsentrasi madu, didapatkan nilai terendah sebesar 5,05 dari konsentrasi madu $30 \%$ dan $45 \%$. Sedangkan nilai tertinggi sebesar 7,4 didapatkan dari konsentrasi madu $15 \%$.

Hasil analisis Uji Friedman $(\alpha=0,05)$ menunjukkan bahwa uji perbandingan pada tiga konsentrasi madu memberikan pengaruh nyata terhadap rerata kesukaan aroma madu. Kombinasi perlakuan terbaik tingkat kesukaan aroma diperoleh dari konsentrasi madu $15 \%$, dimana sebagian besar panelis sangat menyukai aroma minuman yang tidak terlalu tajam.

Pollnitz et al. (2000) melaporkan bahwa senyawa 4Ethylguaiacol merupakan senyawa aroma yang utama dalam minuman alkohol anggur merah. Senyawa ini pun dapat digunakan untuk memantau keberadaan jenis ragi Brettanomyces dalam minuman anggur merah.

Karbohidrat dalam madu mempunyai potensi untuk meningkatkan intensitas flavor yang diinginkan. Kabohidrat dalam madu, seperti dekstrin, oligo-, didan mono sakarida berasal dari pati yang diubah oleh enzim diastase (National Honey Board, 2005).

\section{Pemilihan Perlakuan Terbaik Tahap II}

Penentuan perlakuan terbaik pada penelitian tahap II dilakukan dengan menggunakan metode indeks efektifitas (Susrini 2005). Metode ini dilakukan pada parameter organoleptik yang meliputi; rasa, warna dan aroma. Perhitungan untuk penentuan perlakuan terbaik dari konsentrasi madu disajikan pada Lampiran dan hasil penilaian perlakuan terbaik disajikan pada Tabel 11. 
Jurnal Teknologi Pangan Vol.3 No.1

Juni 2012

Tabel 11. Penilaian Perlakuan Terbaik terhadap Parameter Organoleptik (Rasa, Warna dan Aroma) pada Berbagai Kombinasi Perlakuan Tahap II

\begin{tabular}{|c|c|c|}
\hline $\begin{array}{c}\text { Ekstrak Kelopak } \\
\text { Rosella }\end{array}$ & $\begin{array}{c}\text { Konsentrasi Madu } \\
(\boldsymbol{\%} \mathbf{~ v / v})\end{array}$ & Skor \\
\hline \multirow{2}{*}{$\begin{array}{c}\text { Dipanaskan selama } \\
10 \text { menit }\end{array}$} & 15 & $0,810^{*}$ \\
\cline { 2 - 3 } & 30 & 0,410 \\
\cline { 2 - 3 } & 45 & 0,390 \\
\hline
\end{tabular}

$*=$ perlakuan terbaik

Data dalam Tabel 11 menunjukkan bahwa kombinasi perlakuan terbaik pada tahap II untuk parameter organoleptik dari kombinasi ekstrak kelopak rosella kering yang dipanaskan selama 10 menit terhadap berbagai perlakuan konsentrasi madu diperoleh dari kombinasi konsentrasi madu $15 \%$. Parameter organoleptik dari perlakuan terbaik tahap II adalah: rerata kesukaan panelis terhadap rasa 7,65 (sangat suka), warna 3,96 (suka) dan aroma 7,4 (sangat suka). Sedangkan parameter aktifitas antioksidannya adalah: kemampuan minuman fungsional rosella madu untuk menangkap radikal bebas $\mathrm{DPPH}^{-}$sebesar 30,23 $\pm 0,27 \%$; total fenol sebesar $0,59 \pm 0,54 \mathrm{mg} / \mathrm{g} ;$ dan total antosianin sebesar 1,24 $\pm 0,29$ $\mathrm{mg} / \mathrm{g}$.
Winarti dan Nurdjanah (2005) menjelaskan bahwa pangan fungsional dikonsumsi sebagaimana layaknya makanan atau minuman, mempunyai karakteristik sensori berupa penampakan, warna, tekstur dan cita rasa yang dapat diterima oleh konsumen, serta tidak memberikan kontrandikasi dan efek samping terhadap metabolisme zat gizi lainnya jika digunakan dalam jumlah yang dianjurkan.

Komponen Antioksidan pada Perlakuan Terbaik Tahap II Analisis Senyawa Antioksidan Perlakuan Terbaik Tahap II Menggunakan GC-MS

Kromatogram GC-MS dan senyawa-senyawa hasil identifikasi GC-MS minuman fungsional rosella madu disajikan pada Gambar 8. 


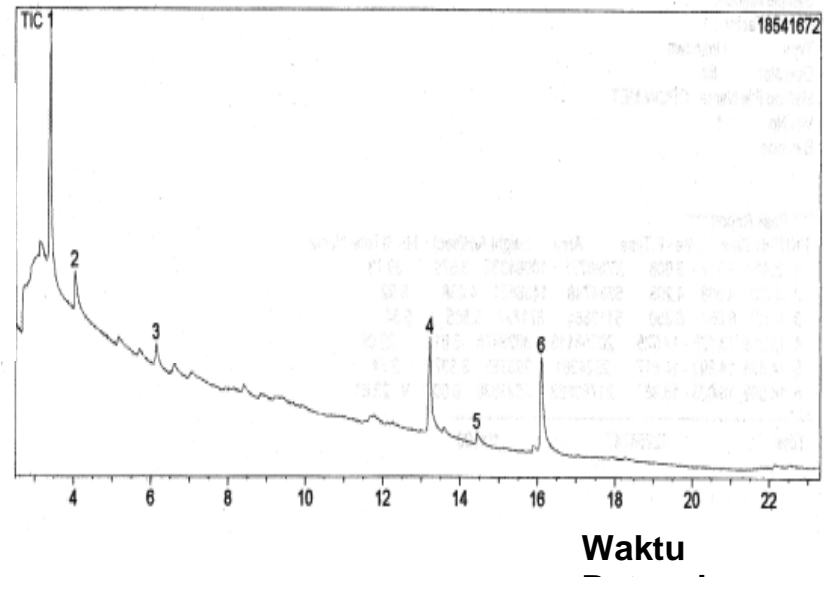

\section{Gambar 8. Kromatogram GC-MS Minuman Fungsional Rosella Madu}

Gambar 8 menunjukkan senyawa-senyawa dominan minuman fungsional rosella madu yang teridentifikasi oleh GC-MS, yaitu acetic acid pada puncak nomor $1(39,13 \%)$, hydroxy methyl furfurole pada puncak nomor 6 $(23,61 \%)$ dan 4H-pyran-4-one, 23 dihydro 3,5 dihidroxy 6 methyl pada puncak nomor 4 (22,06\%). Komponen utama minuman fungsional rosella madu ditampilkan pada Tabel 12 .
Data dalam Tabel 12 menjelaskan mengenai senyawasenyawa yang dihasilkan dari kombinasi ekstrak kelopak rosella kering yang dipanaskan selama 10 menit dengan konsentrasi madu sebesar $15 \%$ (v/v). Senyawa yang berasal dari madu menurut Verzera, Campisi, Zappala and Bonnacorsi (2001) adalah acetil acid $(4,5 \%)$ dan hydroxy methyl furfurole $(3,5 \%)$ pada madu jeruk, methyl pyrovate dan levulinic acid.

Tabel 12. Komponen Utama Minuman Fungsional Rosella Madu 
Jurnal Teknologi Pangan Vol.3 No.1

Juni 2012

\begin{tabular}{|c|l|l|l|}
\hline $\begin{array}{c}\text { No } \\
\text { Puncak }\end{array}$ & \multicolumn{1}{|c|}{ Senyawa yang Muncul } & \multicolumn{1}{|c|}{ Nama IUPAC } & \multicolumn{1}{c|}{$\begin{array}{c}\text { Gologan } \\
\text { Senyawa }\end{array}$} \\
\hline 1 & Acetil acid* & Ethanoic acid & $\begin{array}{l}\text { Asam } \\
\text { Karboksilat } \\
\text { Alkohol }\end{array}$ \\
2 & Acetol & $\begin{array}{l}\text { 2-acetyloxybenzoic } \\
\text { acid }\end{array}$ & Ester \\
3 & Methyl pyrovate* & $\begin{array}{l}\text { 4H-pyran-4-one,2,3 dihydro 3,5 } \\
\text { dihydroxy 6 methyl }\end{array}$ & $\begin{array}{l}\text { 3,5-dihydroxy-6- } \\
\text { methyl-2,3- } \\
\text { dihydropyran-4-one }\end{array}$ \\
5 & Levulinic acid* & $\begin{array}{l}\text { K-Oxopentanoic } \\
\text { acid }\end{array}$ & $\begin{array}{l}\text { Asam } \\
\text { karboksilat }\end{array}$ \\
6 & Hydroxy methyl furfurole* & $\begin{array}{l}\text { 5-(hydroxymethyl)- } \\
\text { 2-furaldehyde }\end{array}$ & Furufural \\
\hline
\end{tabular}

Analisis Gugus Fungsional Perlakuan Terbaik Tahap II Menggunakan Fourier Transform Infra Red (FTIR) Spektofotometri

Kromatogram FTIR hasil identifikasi dari minuman fungsional rosella madu disajikan pada Gambar 8. Sebanyak 13 gugus fungsional minuman fungsional rosella madu yang teridentifikasi oleh spektrum inframerah, yaitu: gugus fenol, alkena tersubstitusi, alkohol primer $\left(-\mathrm{CH}_{2} \mathrm{OH}\right)$, alkohol sekunder ($\mathrm{CHROH}$ ), eter (R-O-R), aldehida ( $\mathrm{R}-\mathrm{CHO}), \mathrm{C}=\mathrm{C}$ aromatik, keton (R-CO-R), alkana metal (- $\left.\mathrm{CH}_{3}-\right)$, asam karboksilat $(\mathrm{RCOOH})$ dan $\mathrm{OH}$. Sedangkan untuk bilangan gelombang 2078,16 dan 2360,71 $\mathrm{cm}^{-1}$ tidak dapat dikenali dari spektrum inframerah, hal ini diduga energi getarannya relatif rendah.

Gambar 9 menunjukkan spektrum inframerah dari minuman fungsional rosella madu, dimana memberikan serapan utama pada bilangan gelombang $3425,34 \mathrm{~cm}^{-1}$ (kuat lebar) yang khas untuk regangan gugus $\mathrm{OH}$ dan bilangan gelombang 1631,67 $\mathrm{cm}^{-1}$ (kuat tajam) untuk regangan gugus aromatik. Menurut Sikora et al. (2008), antioksidan 
berhubungan dengan struktur dasar dari susunan rantai karbon heterosiklik, dimana salah satunya adalah lokasi dari kelompok hidroksil $(\mathrm{OH})$ yang membentuk menjadi kelompok metoksil $\left(\mathrm{OCH}_{3}\right)$ dan sisanya adalah glikosida. Gugus fungsional dari minuman fungsional rosella madu disajikan pada Tabel 13.

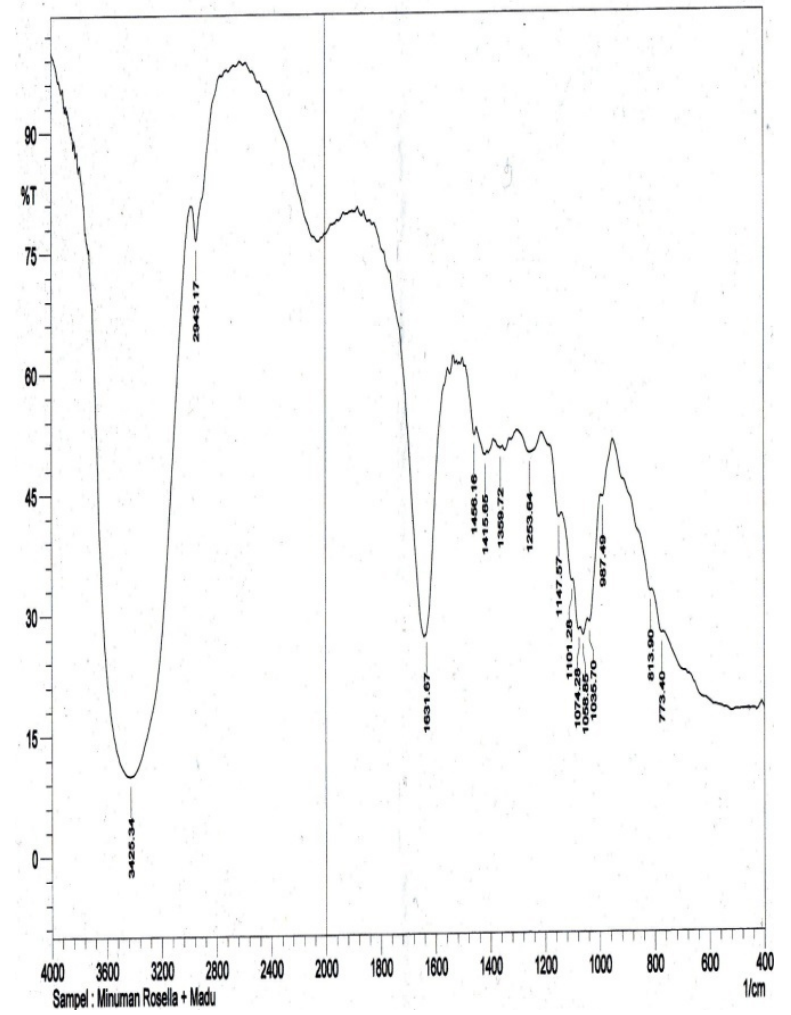

Gambar 9. Spektrum Inframerah Minuman Fungsional Rosella Madu 
Data dalam Tabel 13 madu seperti alkohol dan aldehida menunjukkan bahwa tidak termasuk ke dalam kelompok ditemukannya gugus fenol, asam oxigenated. Hasil analisa GC-MS karboksilat, ester dan alifatik diidentifikasi senyawa yang apabila dibandingkan dengan termasuk dalam kelompok spectrum inframerah esktrak oxygenated pada minuman kelopak rosella yang dipanaskan fungsional rosella madu adalah selama 10 menit pada Tabel 7.

Gugus fungsi yang muncul pada minuman fungsional rosella acetol $(6,92 \%)$ dan 4H-pyran-4one, 2,3 dihydro 3,5 dihydroxy 6 methyl $(22,06 \%)$.

Tabel 13.Analisis Gugus Fungsional Minuman Fungsional Rosella Madu Menggunakan Fourier Transform Infra Red (FTIR)

\begin{tabular}{|l|c|l|l|}
\hline No & $\begin{array}{c}\text { Bilangan } \\
\text { Gelombang } \\
\left(\mathbf{c m}^{-1}\right)\end{array}$ & \multicolumn{1}{|c|}{ Jenis Vibrasi } & \multicolumn{1}{|c|}{ Gugus Fungsi } \\
\hline 1 & 773,40 & CH bend kel. bid. & Aromatik \\
2 & 813,90 & CH bend kel. bid. & Aromatik \\
3 & 987,49 & CH bend trans & Alkena $(-\mathrm{CH}=\mathrm{CH}-)$ \\
4 & 1035,70 & C-OH stretch & Alkohol $\left(-\mathrm{CH} \mathrm{H}_{2} \mathrm{OH}\right)$ \\
5 & 1058,85 & C-OH stretch & Alkohol $(-\mathrm{CHROH})$ \\
6 & 1074,28 & - & - \\
7 & 1101,28 & C-OH stretch & Alkohol $(-\mathrm{CHROH})$ \\
8 & 1147,57 & - & - \\
9 & 1253,64 & C-O-C stretch alkil-aril eter & Eter $(\mathrm{R}-\mathrm{O}-\mathrm{R})$ \\
10 & 1359,72 & H-C=O bend. Alifatik aldehid & Aldehida (R-CHO) \\
11 & 1415,65 & H-C=O bend. Alifatik aldehid & Aldehida (R-CHO) \\
12 & 1456,16 & Ring aromatik stretch $(4 \mathrm{p})$ & Aromatik \\
13 & 1631,67 & Ring aromatik stretch $(4 \mathrm{p})$ & Aromatik \\
14 & 2943,17 & CH stretch dalam C-CH ${ }_{3}$ & Alkana $\left(\mathrm{Metil}-\mathrm{CH}_{3}-\right)$ \\
15 & 3425,34 & OH stretch H bonded & OH \\
\hline
\end{tabular}




\section{KESIMPULAN DAN SARAN Kesimpulan}

1. Perlakuan kondisi bahan baku kelopak rosella kering yang dipanaskan selama 10 menit merupakan perlakuan terbaik dengan sifat kimia, yaitu: kemampuan kelompak rosella kering untuk menangkap radikal bebas $\mathrm{DPPH}^{-}$sebesar $75,59 \pm 0,38 \%$, total fenol sebesar 6,491 $0,34 \mathrm{mg} / \mathrm{g}$ dan total antosianin sebesar 3,862 \pm $0,18 \mathrm{mg} / \mathrm{g}$. Hasil analisa menggunakan GC-MS diidentifikasi senyawa hydroxyl methyl furfurole $41,14 \%$ yang berperan sebagai antioksidan.

2. Konsentrasi madu $15 \%$ (v/v) merupakan perlakuan konsentrasi terbaik dengan sifat kimia dan organoleptik, yaitu kemampuan

minuman fungsional rosella madu untuk menangkap radikal bebas $\mathrm{DPPH}^{-}$sebesar 30,23 $\pm 0,27 \%$; total fenol sebesar $0,59 \pm 0,54$ $\mathrm{mg} / \mathrm{g}$; dan total antosianin sebesar 1,24 $\pm 0,29 \mathrm{mg} / \mathrm{g}$; skor rasa 7,65 (sangat suka), warna 3,96 (suka) dan aroma 7,4 (sangat suka). Hasil analisa menggunakan GC-MS diidentifikasi senyawa hydroxyl methyl furfurole $(3,5 \%)$ yang berperan sebagai antioksidan

\section{Saran}

1. Minuman rosella madu dapat digunakan sebagai salah satu alternatif minuman fungsional tanpa bahan kimia yang disenangi oleh konsumen dan mengandung senyawa antioksidan alami.

2. Penelitian dapat dilanjutkan dengan bagian dari rosella seperti biji atau bunga rosella atau kombinasi beberapa tanaman herbal dengan penambahan madu untuk dijadikan sebagai minuman antioksidan.

\section{DAFTAR PUSTAKA}

Al-Mamary, M., A. Al-Meeri and M. Al-Habori. 2002. Antioxidant Activities and Total Phenolics of Different Types of Honey. Abstrak Nut. Res, 22 (9): 1041-1047.

Baltrušaityte, $\quad$ V., $\quad$ P. R. Venskutonis dan V. Čeksterytė. 2005. Radical Scavenging Activity of Different Floral Origin Honey and Beebread 
Phenolic Extracts. Food Chem, 101 (2): 502-514.

Brown, M. J., D. E. Henderson and C. Hunt. 2006. Comparison of Antioxidant Properties of Supercritical Fluid Extracts of Herbs and the Confirmation of Pinocembrin as a Principle Antioxidant in Mexican Oregano (Lippa Gravolens). EJEAFChe, 5 (2): 1265-1277.

Clode, S. A., J. Hooson and W. H. Butler. 2001. British Industrial Biological Research Association. Carshalton. Surrey. England. $w w w$ colouring agents.com. Diakses tanggal 23 Februari 2010.

Chumsri, P., A. Sirichote and A. Itharat. 2008. Studies on The Optimum Conditions for The Extraction and Concentration of Roselle (Hibiscus sabdariffa Linn.) Extract. Songklanakarin J. Sci. Technol., 30 (Suppl.1): 133-139.

D'Arcy, B. R. 2005. Antioxidants in Australian Floral Honeys : Identification of Health-
Enhancing Nutrient Components. A report for the Rural Industries Research and DevelopmentCorporation.http:// www.rirdc.gov.au/reports/HBE/ 05-040.pdf. Diakses tanggal : 13 Januari 2010.

Duh, P. and G. Yen. 1997. Antioxidative Activity of Three Herbal Water Extracts. Food Chemistry. 60 (4): 639-645.

Frimpong, G. 2008. Investigating The Suitability of Hibiscus Sabdariffa Calyx Extract as Colouring Agent for Paediatric Syrups. Thesis. Master of Pharmacy. Kwame Nmrumah University of Science and Technology. Ghana.

Gheldof, N. and N. J. Engeseth. 2002. Antioxidant capacity of honeys from various floral sources based on the determination of oxygen radical absorbance capacity and inhibition of in vitro lipoprotein oxidation in human serum samples. Abstrak Journal of Agr and 
Food Chem, 50 (10): 30503055.

Hegazi, A. G. and F. K. A. ElHady. 2007. Influence of Honey on the Suppression of Human Low Density Lipoprotein

Peroxidation (In vitro). eCAM, 71: 1-9.

Hirunpanich, V., A. Utaipat, N. P. Morales, N. Bunyapraphatsara, H. Sato, A. Herunsale and C. Suthisisang. 2006.

Hypocholesterolemic and Antioxidant Effects of Aqueous Extracts form The Dried Calyx of Hibiscus sabdariffa L. in Hypercholesterolemic Rats. J. Ethno-Pharmacology. 103: 252260.

Intanwidya, J. 2007. Madu, Si Manis Keemasan. http://www.halalguide.info/inde $x$ 2.php? option $=$ com_content $\& d$ o_pdf $=1 \& i d=793$. Diakses tanggal : 13 Januari 2010.

Kruawan, K. and K. Kangsadalampai. 2006. Antioxidant Activity, Phenolic Compound Contents and Antimutagenic Activity of
Some Water Extract of Herbs. Thai J. Pharm. Sci, , 30: 28-35.

Mazza, G. and E. Miniati. 1993. Anthocyanins in Fruits, Vegetables and Grains. CRC Press Inc. United States of America.

Mehta, A. C. 1994. The Pharmaceutical Journal. Pp25; 84-86.

Mommies, W. R. 2005. Kiat Memilih Madu dan Khasiatnya. $\quad$ http://wrmindonesia.org/index2.php?optio $n=$ content $\& d o \_p d f=1 \& i d=342$. Diakses tanggal : 13 Januari 2010.

Ruangsri, P., P. Chumsri, A. Sirichote and A. Itharat. 2008. Changes in Quality and Bioactive Properties of Concentrated Roselle (Hibiscus sabdariffa Linn.) Extract. As. J. Food Ag-Ind., 1 (02): 62-67.
Rusfidra.
2006. Prospek Pengembangan Budidaya Perlebahan di Indonesia. Seminar Nasional Biologi 
Diselenggarakan oleh Fakultas MIPA Universitas Negeri Semarang.

Sampoerno dan D. Fardiaz. 2001. Kebijakan dan

Pengembangan Pangan Fungsional dan Suplemen di Indonesia. Dalam I. Nuraida dan R.D. Hariyadi (Ed.). Pangan Tradisional Basis Bagi Industri Pangan Fungsional dan Suplemen. Pusat Kajian Makanan Tradisional. Institut Pertanian Bogor. Bogor. Halaman 1-15.

Standar Nasional Indonesia. 2004.

Madu.

www.ebookpangan.com/EBOO

K\%20GRATIS/Ebook\%20Pang an/SNI-01-3545-

2004\%20(madu).pdf Diakses tanggal : 13 Januari 2010.

Subrahmanyam, M. 2007. Topical Application of Honey for
Burn Wound Treatment-An

Overview. Annals of Burns and Fire Disasters, 22 (1) :2.

Tsai, P., J. McIntosh, P. Pearce, B. Camden and B. R. Jordon. 2002. Anthocyanin and antioxidant capacity in Roselle (Hibiscus Sabdariffa) extract. Food Research International. 35(4): 351-356.

Weiner, M. A. 1994. Herbal Antioxidants in Clinical Practice. Journal of Orthomolecular Medicine, 9 (3): 167-176.

Wong, S. K., Y. Y. Lim and E. W. C. Chan. 2009. Antioxidant Properties of Hibiscus: Species Variation, Altitudinal Change, Coastal Influence and Floral Colour Change. Journal of Tropical Forest Science, 21 (4): 307-315. 